\title{
Georges Simenon, Inspector Maigret and his relevance to the practice of Neurology
}

Georges Simenon, Inspector Maigret e a sua relevância para a prática da Neurologia

Hélio A. G. Teive', Andrew J. Lees²

\begin{abstract}
Georges Simenon's work, including his famous 'romans durs' novels and the forensic investigations carried out by his artistic creation, Inspector Maigret, bear many similarities to some of the diagnostic methods of the founders of Neurology, particularly Jean-Martin Charcot.

Keywords: literature; neurology.
\end{abstract}

\section{RESUMO}

A obra de Georges Simenon, incluíndo os seus famosos "romances duros", e as investigações criminais realizadas pela sua criação artística, o comissário Maigret, tem muitas similaridades com alguns métodos diagnósticos utilizados pelos fundadores da Neurologia, particularmente Jean-Martin Charcot.

Palavras-chave: literatura; neurologia.

The links between neurology and the nineteenth century novel have long been a source of scholarly interest but connections with detective fiction have only recently begun to be explored $^{1,2,3}$. Forensic medicine and neurology both emerged as distinct specialties in the middle of the nineteenth century and some of the early neurologists like Brouardel in Paris and Ferrier in England held joint appointments between the two disciplines $^{3,4}$. Many authors of crime novels such as Edgar Allan Poe (detective Auguste Dupin), Agatha Christie (Hercule Poirot), Raymond Chandler (Philip Marlowe), Dashiell Hammett (Sam Spade), Arthur Conan Doyle (Sherlock Holmes) and Georges Simenon (Jules Maigret), are popular reading material for numerous neurologists and some even turned their hand to writing detective fiction. ${ }^{3}$ The Maigret detective novels were a phenomenal commercial success, but like Sherlock Holmes for Doyle, the fictional creation became a millstone round Simenon's neck as he strived for serious literary acclaim ${ }^{5,6,7,8,9}$.

\section{GEORGES SIMENON}

Georges Joseph Christian Simenon (1903-1989) was born in Liège, Belgium (Figure 1) and, while still young, moved to Paris, France 5,6,7,8,9. $^{\circ}$.

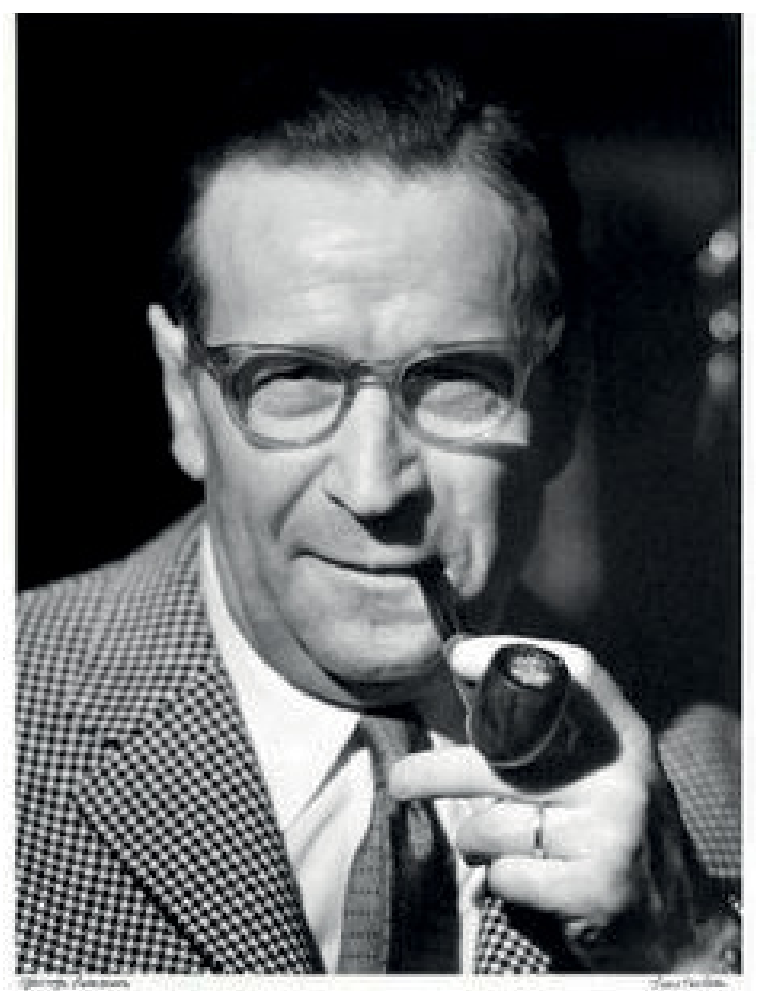

(Extracted from Google Images: www.goodreads.com, February, 13th, 2016). Figure 1. Georges J. C. Simenon (1903-1989).

\footnotetext{
'Universidade Federal do Paraná, Hospital de Clínicas, Departamento de Medicina Interna, Serviço de Neurologia, Curitiba PR, Brasil;

${ }^{2}$ University College London, Institute of Neurology, Reta Lila Weston Institute of Neurological Sciences, UK.

Correspondence: Hélio A. G. Teive; Rua General Carneiro, 1103/102; 80060-150Curitiba PR; Brasil; Email: hagteive@mps.com.br

Conflict of interest: There is no conflict of interest to declare.

Received 20 February 2016; Accepted 03 March 2016.
} 
Simenon's work can be divided into the 'romans durs' novels, in which he explores the daily drama of the lives of ordinary people, and his crime novels featuring his famous creation, Inspector Jules Maigret of the French Judicial Police $e^{5,6,7,89}$. Inspector Maigret, the central character in 75 of Simenon's 400 novels and 28 of his short stories, gained a level of international acclaim comparable to that achieved by Sherlock Holmes and Hercule Poirot, although his star has faded somewhat in recent years. Simenon's ability to write gripping crime novels and psychological dramas may have stemmed from his family background and his early work as a crime reporter on the Gazette de Liège, in Belgium. He died at the age of 86 in Lausanne, Switzerland ${ }^{5,6,7,8,9}$.

\section{INSPECTOR MAIGRET}

Commissioner, or Inspector, Jules A. F. Maigret (Figure 2) of the French Police, had a distinctive method for solving crimes that differed considerably from the more scientific method of deductive reasoning backwards from the crime that characterized Sherlock Holmes' modus operandi. Maigret's was far more intuitive and his success depended on a deep understanding of human behaviour ("a dive into the human soul" $)^{5,6,7.8}$. His approach owed more to psychology, whereas Holmes embraced pathology and modern scientific advances such as fingerprinting. Maigret first soaks up the atmosphere of the

crime scene and analyses, in exhaustive detail, the psychological profiles of the main suspects ${ }^{5,6,7.8}$. Maigret is depicted in the novels as a corpulent, sedentary, slothful and bad tempered man of few words, famous for his love of food and drink. He is portrayed on screen with his trademark hat, an overcoat with a velvet collar, sucking on his pipe ${ }^{5,6,7.8}$. In the book Memoirs of Maigret, the reader learns that the famous inspector studied medicine as a young man, only to give it up and start a career in the police.

Simenon often hints that Maigret's partial knowledge of medicine helps him to solve some of the crimes he investigated.

\section{SIMENON AND NEUROLOGY}

In his book The Bells of Bicêtre, published in 19637, Simenon details the medical history of Mr. René Maugras, a 55-year-old Parisian magnate who has a stroke during lunch at a famous Parisian restaurant, leaving him paralyzed down the right side and unable to express himself. He then falls into a coma, and is diagnosed with thrombosis of the left middle cerebral artery ${ }^{7}$. The patient's clinical course, with severe neurological deficits, his rehabilitation and the anguish he and his family feel as his condition worsens are described with great attention to detail and accuracy?

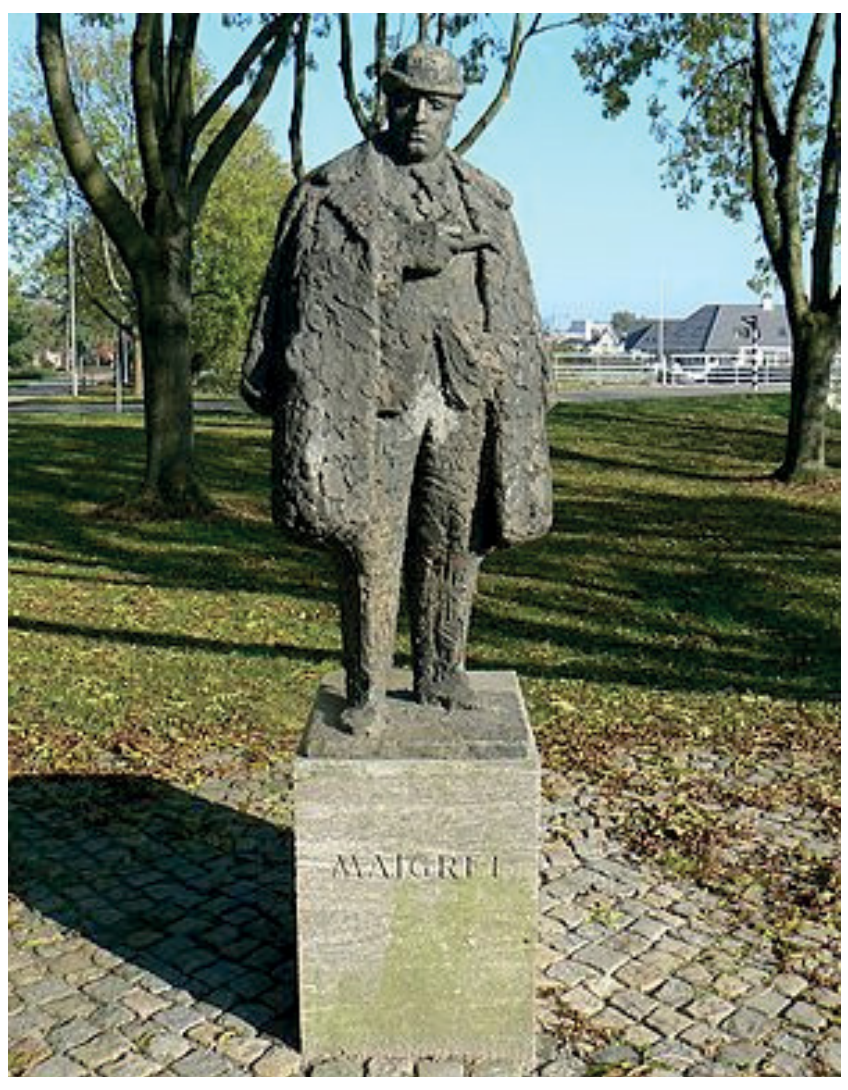

(Extracted from Google images: en.wikipedia.org, February, 13th, 2016). Figure 2. Inspector Jules Maigret statue (by Pieter d'Hont, in Delfzjl, The Netherlands).

\section{SIMENON AND PSYCHIATRY}

In one of Simenon's most famous books, Dirty Snow, published in $1948^{6}$, the main character, 19-year-old Frank Friedmaier is a pimp, a crook and a thief who lives in France under the Nazi occupation. His mother runs a brothel, which is frequented by German officers ${ }^{6}$. Frank's indifference, his mendacity and his complete callousness and lack of any feeling of remorse for the crimes he commits, provides a clear description of sociopathy ${ }^{6}$. Even after he is sent to prison, Frank remains emotionally detached from his mother, friends and even a supposed admirer 6 .

\section{DISCUSSION}

Simenon describes psychological and psychiatric disorders in a way that clearly shows the "absurdity of human existence" and leads to Simenon being considered "a clinician of the soul"5,6,7,8,9. In his book My Friend Maigret, 5 Simenon describes in detail the visit of an inspector from Scotland Yard, Mr. Pyke, to the French Judicial Police. The purpose of the visit is for Pyke to learn from how Maigret operates ${ }^{5}$. To Pyke’s amazement, Maigret follows no scientific method of investigation but, literally, enters the inner world of his victim, reconstructing psychological and social profiles. His 
technique involves protracted interviews that eventually end with the perpetrators confession ${ }^{5}$.

One of Charcot's great legacies as a clinician was his contribution to the development of systematic neurological examination. Charcot attempted to link clinical signs to specific anatomical lesions in the nervous system. He was a visionary who used Gallic intuitiveness and showmanship to great effect, in both his clinical demonstrations and teaching seminars. Maigret's approach to crime solving reminds us that neurology can never be reduced to a series of guidelines and algorithms and that, although a systematic approach may enable a clinician to come to the correct diagnosis, if he is to cure his patient's ailment he will require 'know how' and tacit knowledge of human behavior as exemplified by Jules Maigret in his everyday business of bringing murderers to justice $e^{5,6,7,8,9,10}$.

\section{References}

1. Iniesta I. [Neurology and literature]. Neurologia. 2010;25(8):507-14. Spanish. https:// doi.org/10.1016/j.nrl.2010.07.013

2. Teive HAG, Munhoz RP, Paola L. Neurological diseases in the Dalton Trevisan's short stories. Acta Med Port. 2014;27(2):232-5.

3. Kempster PA, Less AJ. Neurology and detective writing. Pract Neurol. 2013;13:372-6. https://doi.org/10.1136/practneurol-2013-000597

4. Lees AJ. The strange case of Dr. William Gowers and Mr. Sherlock Holmes. Brain. 2015;138:2103-8. https://doi.org/10.1093/brain/awv144
5

Simenon G. Meu amigo Maigret. Porto Alegre: LPM; 2013. (LPM Pocket, Vol 1103).

6. Simenon G. A neve estava suja. São Paulo: Companhia das Letras; 2014.

7. Simenon G. The bells of Bicêtre. New York: Harcourt, Brace \& World; 1964.

8. Simenon G. Memórias de Maigret. Porto Alegre: LPM; 2006.

9. Simenon G. Pedigree. New York: Review of Books; 2010.

10. Teive HAG, Munhoz RP, Silva GG. Charcot's skepticism. Arq Neuropsiquiatr. 2012;70(11):897-9. https://doi.org/10.1590/S0004-282X2012001100014 